\title{
Effects of short-term training on pastoral community employment creation and livelihood improvement: a study on selected Ethiopian pastoral areas
}

Robson Mekonnin Shiferaw (1)

$\overline{\text { Correspondence: Robsonkee@gmail. }}$ com

College of Business and Economics, Haramaya University, Haramaya, Oromia, Ethiopia

\begin{abstract}
This study investigated the effects of a short-term training on pastoral community employment creation and livelihood improvement. The study investigated the perception of beneficiaries pertinent to the benefits of a short-term training scholarship, experiences of graduate trainees, estimation of employability rate after training, and types of employment TVET graduates are engaged during the year 2014 to 2017 in Pastoral Resilience Improvement through Market Extension project operating clusters. Self-administered survey questionnaires were used and distributed to 128 project beneficiaries in Afar, Eastern, and Southern clusters of Ethiopia. Since the instrument was close-ended questionnaires in the form of a dichotomous, and quantitative research approach was deployed. The quantitative part of the assessment was analyzed using descriptive and inferential statistics with the support of SPSS version 20. The finding of the study indicated that the reasons for unemployment of the beneficiaries were mainly lack of financial support and poor industry linkage with employers in the areas. On the other hand, such activities should be assessed once again for financial and material support since the majority of the trainees were unemployed and seeking support besides the training received from the program in all clusters from all concerned development partners. The finding of the study depicted, gender-related issues in all clusters implies that women involvements or participation shows a variation in some clusters. However, the project more benefited male beneficiaries than women in all clusters. Therefore, if the project will continue this type of program, balancing gender and equal benefit should be maintained in all clusters. Redesigning the program is required because due to providing training alone cannot bring livelihood changes as the finding of the study revealed. This is because the beneficiaries of the program were selected from an economically poor family background. Therefore, the program should evaluate once again for financial and equipment support since the majority of the trainees were unemployed and seeking support from different development stakeholders in the three clusters.
\end{abstract}

Keywords: Short-term training, Livelihood change, Job creation, Pastoral, Community 


\section{Introduction}

The government believes that the present low factor productivity is due to the skill gap that when left on its own, the industry will provide less training than what is socially optimal. Publicly provided vocational education is seen by the government as the means to close this skill gap. Even if the arguments for centrally directed TVETs were convincing, ensuring that such a non-market-based system improves the outcomes of its beneficiaries is challenging in practice (Krishnan and Shaorshadze 2013). Fostering Economic Prosperity through small and microbusinesses at the grass-root level is done by identifying income-generating opportunities in farm and non-farm sectors and providing training for the incubated groups in technical and non-technical areas. This increases the livelihood capacity and employability in the rural communities (Samineni 2018). Institutions involved in developing human resources through long- and short-term programs have the duty to keep track of the performance of their graduates to determine accountability and whether or not their human resource development programs have an impact on the individual, the institution, or the country (CEIQA 2009). Motivators such as extrinsic rewards and change management inspire them to start up a new venture whilst the government support/assistance plays a significant role in promoting entrepreneurship. By contrast, obstacles and challenges such as endogenous factors (financial and operational problems) seemingly hinder their effort to launch a new venture (Ooi and Ahmad 2012). Yildirim et al. (2016) stated two constructs to create a job (attitudes towards behavior and social norms) from the theoretical background; both the perceived value of outcomes (including autonomy, financial performance, personal quality of life) of starting a business and family and friends attitude to entrepreneurial activity that belongs to social valuation dimension of social norms construct.

Implementing agencies usually have a good idea of what the trainees are doing for the duration of the project, and now it ends. However, the challenge is for interventions to produce lasting, long-term results. A study explores what changes occurred in the lives of former beneficiaries, and if and how the intervention contributed to these changes. A more comprehensive goal is to offer insight into which type of interventions, or which type of approaches within an intervention, may have had more impact. Knowing what seems to work better, and in what circumstances, is valuable in any future program planning and decision-making (ILO 2011). A community's capacity built through training to increase wealth and change of livelihood over time critically centers on its potential to develop and share knowledge, thereby influencing economic wellbeing (Braunerhjelm 2010). According to Lowrey (2011), job creation is business creation. Business creation generates not only jobs but also entrepreneurial employments. In the face of high youth unemployment and one of the most severe financial shortages for the youth community, rather than waiting for employment offers, entrepreneurs continue to create businesses and employment for others in the community but most importantly for themselves. The desire to grow a business is not a goal for all entrepreneurs, and therefore, those who do view their future in this way must be afforded tailored support to ensure that they have the best prospects of succeeding. Service providers frequently underestimate this aspect of human capital 
development, but more recently, training programs are offering participants a greater opportunity to develop their social capital through enhanced networking opportunities (Cooney 2012). The policy changes necessary to create such an ecosystem require strong political will and a readiness to challenge entrenched political and economic interests. Pressing banks to extend financing opportunities to entrepreneurs, improving market access through better integrated regional supply chains, and deconstructing non-tariff barriers are highly politicized issues. Policy reforms in these areas have therefore been difficult to implement. Ultimately, however, if governments want to reduce unemployment and financial strain, they should do what is needed to empower entrepreneurs (Essuman 2018). Entrepreneurship is considered crucial to a dynamic economy. Entrepreneurs create employment opportunities not only for themselves but for others as well. Entrepreneurial activities may influence a country's economic performance by bringing new products, methods, and production processes to the market and by boosting productivity and competition more broadly. Start-up subsidies should be considered to foster entrepreneurial activities. Entrepreneurs are equally, if not more, important when the economy is doing badly. When unemployment is high and the economy is contracting or stagnating, dynamic entrepreneurship could help turn the economy around (Kritikos 2014).

Therefore, this study focused on investigating the effects of PRIME-sponsored TVET short-term training graduates in various skills and lessons learned in Afar, Ethiopia Somali, and Borana areas. The study primarily targeted how short-term training made an economic effect on beneficiaries' income, continuity of the activity, lessons learned, identifying areas of intervention, and forwarding policy implications to development partners in the regions where the project operating.

\section{Literature review}

Training and development are directly related to an employee, but its ultimate effect goes to an organization because the end-user is the organization itself. It will also help the organization to understand which factors are important to keep in mind during the training and how a good training can be delivered to their employees. It will help them to understand that it is very necessary for them to give training to their employees so that they could perform the assigned task in a better way (Khan et al. 2011). The major challenge for the training program is how to effectively design and implement a program that has a good balance between literacy training and practical knowledge and skills that can be of immediate use to the learners in improving their living conditions (Oxenham et al. 2002).

A lack of basic skills and education has greatly diminished job possibilities for some workers. The most successful training programs either coordinate directly with employers and industry partners to ensure that their participants receive training in skills that are in demand or include career-oriented counseling that steers trainees to the most valuable coursework. Training funds should be directed to programs with a record of accomplishment of success in improving earnings for the specific target population and to those workers who can benefit the most from those programs and training 
programs should directly engage employer and industry partners (Greenstone and Looney 2011).

Although different types of training programs to be aimed at developing the pastoral community to be productive, to what extent this primary objective has been achieved still remains to be answered. The impact of training in changing pastoral community's livelihood has not been explored extensively so far (Noor and Dola 2011). Entrepreneurship is a worldwide phenomenon with economic growth across the globe that is rendered by the emergence of new and innovative business start-ups (Ayalew and Zeleke 2018). The contemporary issues of challenges of unemployment, exclusion, inequality, economic shocks, poverty, and global warming-oblige us to rethink the way we do business. The needs of large groups in society in industrialized as well as developing countries are not being met effectively by conventional markets nor by the state (ILO 2017).

Many other options also exist that can be implemented from early stage to market release which simultaneously decreases risks and costs, many of which we routinely perform, but it is noteworthy that single actions generate small gains, while comprehensive and cumulative changes significantly increase the value proposition of the innovations (Dando and Lebmeier 2020). Simply creating supportive framework conditions is insufficient. Creating favorable environments for business startups is not leading to the creation of more. In addition, transactional forms of support for less developed countries (e.g., financial assistance) are proving to have limited effectiveness, at least post-start-up (Mason and Brown 2014). Most youths do work, but part-time and in low-skilled jobs in the informal sector, including in subsistence agriculture and urban self-employment. Such employment offers no job security, minimal benefits, low pay, and often unhealthy working conditions. To reach the majority of youth, short- and long-term employment strategies need to take into account the current nature of youth employment across Africa (Dekker and Hollander 2017). Young innovators cannot envision a market for their products; they are less likely to follow through on their ideas. African markets are increasingly dominated by inexpensive, low-quality imports that undercut more expensive, locally produced goods. Governments should implement policies that

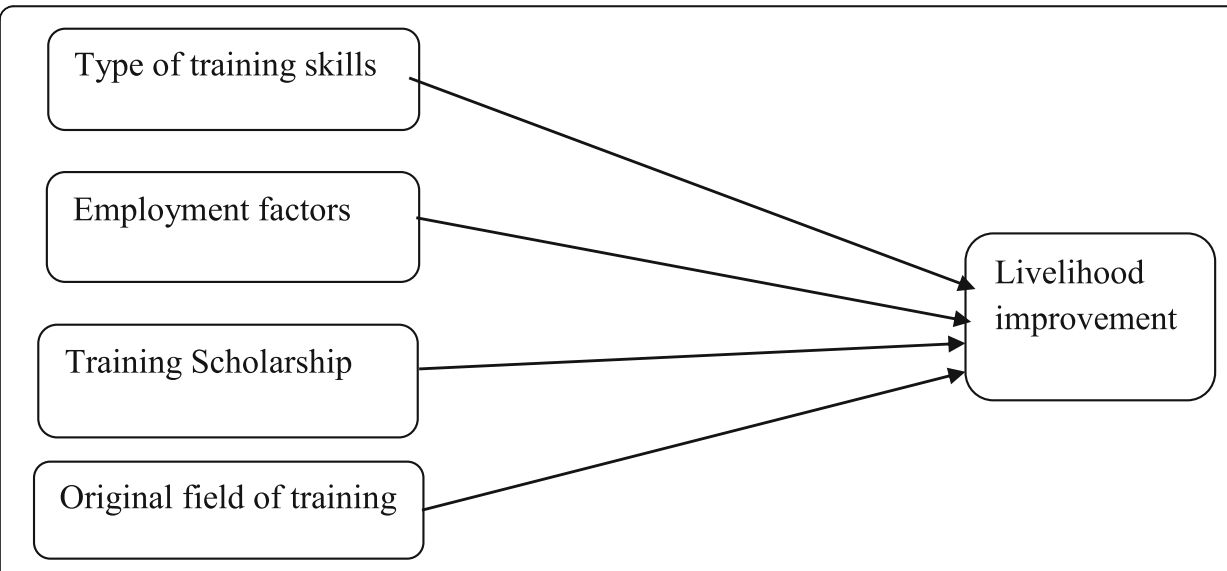

Fig. 1 Conceptual framework. Source: Compiled from a literature review 
Table 1 Sex of respondents

\begin{tabular}{llll}
\hline Sex & Frequency & Percent & Total \\
\hline Female & 41 & 32 & 32 \\
Male & 87 & 68 & 68 \\
Total & 128 & 100 & 100 \\
\hline
\end{tabular}

Source: Survey data 2018

support local production through subsidies, tax breaks, or increased custom fees on imported goods (UNECA 2014). Based on the literature review gap identified, the following variables, i.e., types of skills, employment factors, training scholarships, and original field of training clearly identified and shown in the form of a conceptual diagram (Fig. 1).

\section{Methods}

The study was conducted on the documented profiles of the TVET graduates obtained from lead implementers in Addis Ababa and PRIME intervention areas. There was a scientific literature review about challenges and factors constraining the outcome of the interventions overall in PRIME operating areas. Efforts were made to locate relevant literatures that were conducted in the context of Ethiopian employability type conditions related to this study. In addition to primary sources of data reviewed from the literature, document review of gathering data was developed. Besides secondary sources of data, self-developed survey questionnaires (dichotomous) were distributed to beneficiaries of previous PRIME interventions (TVET graduates sponsored by PRIME project) and lessons learned for 128 samples were randomly selected out of 1500 beneficiaries. Data collected from the beneficiaries based on their perception of a short-term training scholarship received, job search challenges and their experiences, types of employment, and changes in their livelihood effects after the training program.

The collected data analyzed using quantitative data analysis methods. Quantitative data analyzed using descriptive statistics such as frequencies and percentages in the form of table and graph data presentation methods for some variables such as gender, age, type of skills, years of graduation, disability problems, and factors for unemployment. Besides descriptive statistics, binary logistic regression models were used for the major factors affecting the livelihood of a pastoral community through a short-term training. In addition, the $\beta$ coefficients for each independent variable generated from the model were subjected to a chi-square, in order to test the relation of each of independent and dependent variable under the study.

Table 2 Age of sponsored TVET trainees

\begin{tabular}{llllllll}
\hline Age of trainees & $N$ & Range & Minimum & Maximum & Sum & Mean & Std. deviation \\
\hline Minimum value of the age range & 128 & 18 & 0 & 18 & 2002 & 15.64 & 10.242 \\
Maximum value of the age range & 128 & 25 & 0 & 35 & 3650 & 28.52 & 19.601 \\
\hline
\end{tabular}


Table 3 Graduation year of training scholarship awarded trainees

\begin{tabular}{llll}
\hline Item & Frequency & Percent & Total \\
\hline 2014 & 32 & 25 & 32 \\
2015 & 4 & 3.1 & 3.1 \\
2016 & 91 & 71.1 & 71.1 \\
2017 & 1 & 0.8 & 0.8 \\
Total & 128 & 100 & 100 \\
\hline
\end{tabular}

Source: Survey data 2018

\section{Results and discussion}

This section has been subclassified as descriptive analysis and inferential analysis. In a descriptive analysis, frequency tables and percentages have been used in-depth. In the second section, mainly binary logistic regression analysis used to identify the influence of explanatory variables on the effects of a short-term training on livelihood change through business creation engagements.

\section{Descriptive research outputs}

In this section, tabular analysis and relative frequency measures were used to assess the effects of short-term training on pastoral community employment creation and livelihood improvement.

\section{Respondents profile}

Table 1 indicated $87(68 \%)$ of the respondents were male and $41(32 \%)$ of the respondents were female. Thus, one can infer that among the PRIME projectsponsored TVET graduate sample taken depicts, the majority of a short-term training sponsorship was awarded to males in the three clusters of project areas.

Table 2 shows the age of the graduates' ranges from 18 to 25 . In addition, the mean of minimum value of the age range is 15.64 and the mean age of maximum value of the age range is 28.52. Besides the standard deviation of the minimum value of age range 10.242, the maximum value of age range standard deviation is 19.601 . This

Table 4 TVET hosting short-term training graduates from 2014 to 2017

\begin{tabular}{lllll}
\hline TVETs & Cluster & Frequency & Percent & Total \\
\hline Chora driving & Afar & 8 & 6.3 & 6.3 \\
Jigjiga & Eastern & 1 & .8 & 7.0 \\
Jigjiga & Eastern & 33 & 25.8 & 32.8 \\
Kadapa & Afar & 2 & 1.6 & 34.4 \\
Moyale & Southern & 9 & 7.0 & 41.4 \\
Negele & Southern & 28 & 21.9 & 63.3 \\
Sami Billo & Afar & 4 & 3.1 & 66.4 \\
Yabelo & Southern & 43 & 33.6 & 100.0 \\
Total & & 128 & 100.0 & \\
\hline
\end{tabular}


Table 5 Disability problem

\begin{tabular}{llllll}
\hline Variable & & Frequency & Percent & Valid percent & Cumulative percent \\
\hline Do you have disability problem? & No & 90 & 70.3 & 70.3 & 70.3 \\
& Yes & 38 & 29.7 & 29.7 & 100.0 \\
& Total & 128 & 100.0 & 100.0 & \\
\hline
\end{tabular}

Source: Survey data 2018

implies the project considered age disaggregation during the scholarship award for the trainees in PRIME operating areas.

Table 3 shows the PRIME project started the training scholarship award to TVET pastoral area students since 2014 to the beginning of 2017 as it is indicated. The project made the highest award of 91 (71.1\%) scholarships in 2016, and also 32 (25\%) relatively significant scholarship awards were made to the beneficiaries in the three clusters in 2016.

\section{Technical and vocational education trainings}

Table 4 depicts training centers and TVET hosting scholarship award since 2014 to 2017. It can be observed that the majority of the respondents of $80(65.6 \%)$ beneficiaries were from Borana areas (Negele, Yabelo, and Moyale) and the remaining 48 (34.4\%) of beneficiaries were from Eastern and Afar clusters. Thus, one can infer from the above Table 4 the lion share of the analysis was made from Borana areas' training scholarship awards sponsored by the project.

Disability problem distribution among PRIME operating towns

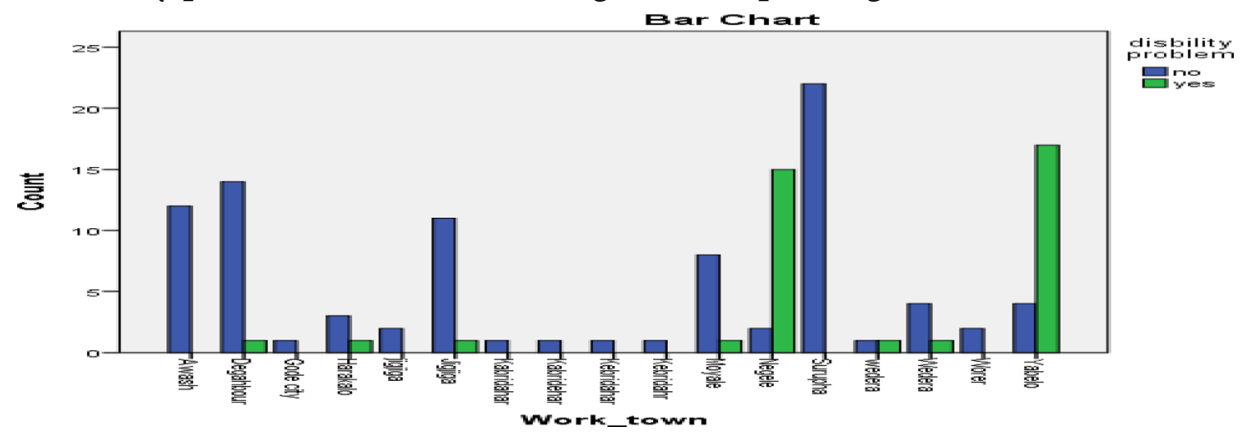

Source: Survey data 2018

The above bar chart shows the majority of people with disabilities were living in Yabelo and Negele (Borana areas) towns comparing with other clusters, and people with disabilities obtained a short-term training at identified public

Table 6 Treatment for people with disability problem

\begin{tabular}{lllll}
\hline \multicolumn{4}{l}{ Treatment for people with disability problem } & \\
\hline No & Frequency & Percent & Valid percent & Cumulative percent \\
Yes & 40 & 31.3 & 31.3 & 31.3 \\
Total & 88 & 68.8 & 68.8 & 100.0 \\
\hline
\end{tabular}

Source: Survey data 2018 
Table 7 Type of skills acquired by the trainees

\begin{tabular}{lllll}
\hline Type of skills & Frequency & Percent & Valid percent & Cumulative percent \\
\hline Drive & 23 & 18.0 & 18.0 & 18.0 \\
Hair dressing & 17 & 13.3 & 13.3 & 31.3 \\
Furniture & 24 & 18.8 & 18.8 & 50.0 \\
Cobble stone & 12 & 9.4 & 9.4 & 59.4 \\
Metal works & 8 & 6.3 & 6.3 & 65.6 \\
Auto mechanics & 6 & 4.7 & 4.7 & 70.3 \\
Others & 38 & 29.7 & 29.7 & 100.0 \\
Total & 128 & 100.0 & 100.0 & \\
\hline
\end{tabular}

Source: Survey data 2018

TVETs working in collaboration with the project. This shows, equal opportunities were not given to the remaining two clusters as of the southern cluster.

Table 5 depicted majority of 90 (70.3\%) of the beneficiaries of the PRIME project were not living with disability problems during the survey data collection. However, 38 (29.7\%) of the project beneficiaries who have a disability problem obtained a short-term training scholarship in PRIME operating areas. This implies that it can be concluded that the project was less inclusive to beneficiaries with disabilities, and they targeted them in the three clusters. However, the lion share of disabilities was living and benefited sponsorship from the project in Borana areas (see in addition the bar chart above).

Table 6 depicts $88(68.8 \%)$ of the respondents indicated the project targeted people with disability problems and equal treatment with others during the scholarship period. However, the remaining $40(31.3 \%)$ of the respondents were not equally treated like beneficiaries of the project. Thus, the majority of respondents of the project beneficiaries agreed that all necessary treatment must equally be given to people with disabilities during the scholarship period.

\section{Types of skill TVET graduate sponsored}

Table 7 shows the project-sponsored skills such as driving, hairdressing, furniture, cobblestone, metal works, auto mechanics, and other types of training skills in the three clusters from 2014 to 2017 at different TVETs and training centers. Therefore, majority of 38 (29.7\%) of the sampled beneficiaries were trained on Garment, Furniture 24 (18.8\%), and Driving 23 (18\%) in the three clusters with a slight variation to types of trainings.

Table 8 Acquired skill is useful for your work

\begin{tabular}{lllll}
\hline Skill acquired usefulness & Frequency & Percent & Valid percent & Cumulative percent \\
\hline No & 17 & 13.3 & 13.3 & 13.3 \\
Yes & 111 & 86.7 & 86.7 & 100.0 \\
Total & 128 & 100.0 & 100.0 & \\
\hline
\end{tabular}

Source: Survey 2018 
Table 9 Original field of training provided to trainees and their current employment situations

\begin{tabular}{lllll}
\hline $\begin{array}{l}\text { Are you working with your original field of } \\
\text { trainings sponsored by PRIME? }\end{array}$ & Frequency & Percent & $\begin{array}{l}\text { Valid } \\
\text { percent }\end{array}$ & $\begin{array}{l}\text { Cumulative } \\
\text { percent }\end{array}$ \\
\hline No & 55 & 43.0 & 43.0 & 43.0 \\
Yes & 73 & 57.0 & 57.0 & 100.0 \\
Total & 128 & 100.0 & 100.0 & \\
\hline
\end{tabular}

Source: Survey data 2018

Table 8 shows the usefulness of types of training (see Table 7) awarded to the trainees from 2014 to 2016 through the PRIME project to the pastoral community. The majority of the sampled beneficiaries of the project who were $111(86.7 \%)$ indicated the usefulness of the skills provided to them. However, the remaining $17(13.3 \%)$ indicated the types of skills provided to them were not useful.

Table 9 shows the majority of 73 (57\%) of the project beneficiaries during the survey collection indicated they were working with the original field of their trainings. On the other hand, 55 (43\%) of the sampled project beneficiaries were not working with what they trained at TVETs and training centers with the sponsorship of the project. This implies that the training and the job opportunities in their surrounding community are not matched.

\section{Employability of sponsored TVET graduate}

Table 10 shows the majority of the project beneficiaries who are 68 (53.1\%) were currently unemployed. However, 60 (46.9\%) of the respondents were employed in the three clusters where the PRIME project is operating. Thus, one can infer from the above Table 10 the majority of respondents were unemployed and seeking jobs. The majority of TVET graduates were unemployed because of financial problems and the lack of job opportunity linkages with industries in PRIME operating areas in general. Thus, the majority of them were wage-based employed for their day-to-day life and seeking future support from all concerned development partners.

\section{Livelihood effect of the program and continuity of the program}

Table 11 shows monthly income before the scholarship provided to trainees at TVETs and training centers. The majority of $102(79.7 \%)$ of the respondents during the survey data collection monthly income obtained from 1 income to 500 (1 to 500 Birr) per month. The remaining respondents obtained monthly income of 21 (16.4\%), 1 (0.78\%), 1 (.78), and 3 (2.34\%) obtained 501 to 1000,1001 to 1500, 1501 to 2000, and 2001 to

Table 10 Current employability status

\begin{tabular}{lllll}
\hline Are you currently employed? & & & \\
\hline Employability status & Frequency & Percent & Valid percent & Cumulative percent \\
\hline No & 68 & 53.1 & 53.1 & 53.1 \\
Yes & 60 & 46.9 & 46.9 & 99.2 \\
Total & 128 & 100.0 & 100.0 & 100.0 \\
\hline
\end{tabular}

Source: Survey data 2018 
Table 11 Monthly income before the scholarship grant to trainees

\begin{tabular}{llc}
\hline Item & Frequency & Percent \\
\hline $1-500$ & 102 & 79.7 \\
$501-1000$ & 21 & 16.4 \\
$1001-1500$ & 1 & 0.78 \\
$1501-2000$ & 1 & 0.78 \\
$2001-2500$ & 3 & 2.34 \\
Total & 128 & 100 \\
\hline
\end{tabular}

Source: Survey data 2018

2500 Birr, respectively. This shows that in the majority, beneficiary livelihood is under economic crisis.

Table 12 shows monthly income before the scholarship provided to TVETs and training center graduates. The majority of $91(71.1 \%)$ of the respondents during the survey collection monthly obtained zero income to 1000 (0 to 1000 Birr) per month. The remaining respondents obtained a monthly income of $13(10.2 \%), 15(11.72 \%), 7$ (5.47\%), and 2 (1.56\%) obtained 1001 to 2000, 2001 to 3000, 3001 to 4000, and 4001 to 5000 Birr, respectively. Thus, the majority of the project beneficiary's income were slightly improved compared with their income before obtaining support from the PRIME project.

Table 13 depicts 125 (96.1\%) of the project respondents were interested in the continuity of such kind of program to other trainees. The remaining $3(2.4 \%)$ of the project respondents were not interested and agreed to the continuity of the program. Thus, the majority of the beneficiaries of the project indicated more demand for this type of program in their localities.

Table 14 indicate the majority of 75 (58.6\%) respondents believed that the support provided to PRIME operating areas to short-term TVET graduates made their livelihood change. However, 53 (41.4\%) of the respondents replied the support obtained from the project did not bring a significant livelihood change due to the training scholarship.

\section{Areas of intervention (Table 15)}

The majority of respondents who are 124 (96.9\%) during the survey period were indicated for financial intervention from the PRIME project or any stakeholders in the

Table 12 Change of monthly income after the scholarship to the trainees

\begin{tabular}{llc}
\hline Item & Frequency & Percent \\
\hline $0-1000$ & 91 & 71.1 \\
$1001-2000$ & 13 & 10.2 \\
$2001-3000$ & 15 & 11.72 \\
$3001-4000$ & 7 & 5.47 \\
$4001-5000$ & 2 & 1.56 \\
Total & 128 & 100 \\
\hline
\end{tabular}

Source: Survey data 2018 
Table 13 Sponsorship continuity

\begin{tabular}{lllll}
\hline & Frequency & Percent & Valid percent & Cumulative percent \\
\hline No & 3 & 2.3 & 2.4 & 2.4 \\
Yes & 125 & 96.1 & 97.6 & 100.0 \\
Total & 128 & 100.0 & & \\
\hline
\end{tabular}

Source: Survey data 2018

future. However, the remaining areas of intervention leasing machine, loan access, and linkage with industry are not more significant. It is clear that the support was provided to them because of their economic disadvantage and lack of training opportunities. Therefore, the majority of them were not employed and not created their own job as a result of financial support.

\section{Inferential analysis output}

Concerning the identification of effects of short-term training on pastoral community employment creation and livelihood improvement, a study on Ethiopian Somali, Southern Oromia, and Afar Pastoral areas using a binary logistic regression model was used. In this case, the model was employed to identify whether the livelihood has improved after the training conducted through training scholarship to young unemployed pastoral areas.

The finding of the study indicates the livelihood changes through employment creation predicted who will not change their livelihood through a short-term training sponsored by the development project after project completion (90.9\%) worse than we can predict who will (69.2\%) (Table 16).

The variables (Table 17) in the equation indicate if we predicted that all the variables would consider all four independent variables in this equation. We would be correct $84.8 \%$ of the time, which is significant, $P=0.005$.

The omnibus tests of model coefficient table (Table 18) indicate that when all four predictors are together, the model is significant (chi-square $=54.777, d f=15, N=128$, $P<0.005)$. Therefore, the overall model is significant when all four independent variables (types of training skills, original field of training, employment factors, and training scholarship) were entered.

The Nagelkerke R Square indicates the model can be used for $64.3 \%$ of the variance in effects of short-term training on pastoral community employment creation and livelihood improvement particularly on Ethiopian Somali, Southern Oromia, and Afar pastoral areas (Table 19).

Table 14 Livelihood change

\begin{tabular}{lllll}
\hline & Frequency & Percent & Valid percent & Cumulative percent \\
\hline No & 53 & 41.4 & 41.4 & 41.4 \\
Yes & 75 & 58.6 & 58.6 & 100.0 \\
Total & 128 & 100.0 & 100.0 & \\
\hline
\end{tabular}

Source: Survey data 2018 
Table 15 Areas of intervention

\begin{tabular}{lllll}
\hline Opinions on future intervention & Frequency & Percent & Valid percent & Cumulative percent \\
\hline Financial support & 124 & 96.9 & 96.9 & 96.9 \\
Leasing machine & 1 & .8 & .8 & 97.7 \\
Loan access & 2 & 1.6 & 1.6 & 99.2 \\
Linkage with industry & 1 & .8 & .8 & 100.0 \\
Total & 128 & 100.0 & 100.0 & \\
\hline
\end{tabular}

Source: Survey 2018

\section{Conclusions}

The study tried to assess the effect of a short-term training program offered to TVET graduates and lessons learned. The findings of the study obtained through close-ended questionnaires in the form of dichotomous designed for the purpose of binary logistic regression and opened survey questionnaires and focus group discussion distributed to 128 project beneficiaries in the three cluster (Afar, Eastern, and Southern) areas. Based on the results of the study conducted, the following conclusions are forwarded.

The study findings indicated the majority of the respondents during the survey period were male beneficiaries of the project comparing with female beneficiaries of the project among the sample survey 68 to $32 \%$, respectively. This shows that the issue of gender in the project was not well considered equally during the scholarship. The project focused on age disaggregation during the scholarship in all clusters where the project is operating. Among 128 sample beneficiaries of the project, 38 (29.7\%) were people with disability problems in all the clusters. However, people with disabilities were from the southern cluster (Negele, Yabelo, and Moyale). In the remaining clusters Afar and Eastern, the attention paid to people with disabilities was not as such significant. The project's purpose was to treat people with disabilities during the sponsorship period. However, the study finding depicted the treatment given to them was not sufficient in comparison with other beneficiaries of the project in some clusters.

The majority of TVET graduates acquired short-term training on garment 38 (29.7\%), furniture 24 (18.8\%), and driving skills 23 (18\%). The skills the TVET graduates obtained during the scholarship from TVETs were very useful for their future career as it indicated their response rate of 111 (86.7\%) to make the program to continue. Some of the beneficiaries of the project responded as they were working with short-

Table 16 Classification table (the cut value is .500)

\begin{tabular}{llllll}
\hline & & & \multicolumn{2}{l}{ Predicted } & \\
\cline { 3 - 4 } & & \multicolumn{2}{l}{ Livelihood change } & & Percentage \\
\cline { 3 - 4 } & & No & Yes & \\
\hline Step 1 & Livelihood change & No & 30 & 4 & 90.9 \\
& & Yes & 4 & 9 & 69.2 \\
& Overall percentage & & & & 84.8 \\
\hline
\end{tabular}


Table 17 Variables in the equation

\begin{tabular}{|c|c|c|c|c|c|c|c|}
\hline & & $B$ & S.E. & Wald & $\mathrm{df}$ & Sig. & $\operatorname{Exp}(B)$ \\
\hline Step 0 & Constant & -.932 & .327 & 8.093 & 1 & .004 & .394 \\
\hline
\end{tabular}

term trainings provided through sponsorship at different TVETs. Besides, most sponsored graduates of TVETs currently not yet employed are 68 (53.1\%) in all the clusters because of different factors.

The findings of the study show the beneficiaries of the project indicated that the reasons for their unemployment were the lack of financial support and poor market linkage with industries in the areas. In addition, the livelihood of the beneficiaries before the support from the project and after the supports given has not significantly provided any difference or change in their current livelihoods. Almost all previously benefited beneficiaries from the PRIME project of 125 (96.1\%) demanded such types of projects to their areas and to their community to continue in the future.

\section{Policy implications}

Based on the conclusions of the study findings, the researcher recommended a policy drafting the effects of the project-sponsored TVET graduates under this study. The study focused on the age of beneficiaries, gender, disability, livelihood change, and lessons learned in the three clusters. Therefore, the researcher recommended the project sponsoring institutions and all development partners to better apply the following recommendations accordingly for policy implications.

Implication 1: gender-related issues in all clusters imply that female involvements or participation shows a variation in some clusters. However, the project more benefited male beneficiaries than a female in all clusters. Therefore, if the project will continue this type of program, balancing gender and equal benefit should be maintained in all clusters.

Implication 2: the program was initially designed to benefit people with disability in all clusters or project operating areas by providing short-term training opportunity sponsorship. However, in all clusters, opportunities given to people with disabilities were highly varied. Thus, it is advisable to follow-up and monitor across the clusters to assure whether the program intended to accomplish its objectives.

Implication 3: the project was designed to provide short-term trainings to youth in the pastoral community of the three selected clusters and assuming job creation will be easy for the participants of the program after training, since the project

Table 18 Omnibus tests of model coefficients

\begin{tabular}{lllll}
\hline & & Chi-square & df & Sig. \\
\hline Step 1 & Step & 54.777 & 15 & .000 \\
& Block & 54.777 & 15 & .000 \\
& Model & 54.777 & 15 & .000 \\
\hline
\end{tabular}


Table 19 Model summary

\begin{tabular}{llll}
\hline Step & -2 Log likelihood & Cox \& Snell R Square & Nagelkerke R Square \\
\hline 1 & $27.500^{\mathrm{a}}$ & .447 & .643 \\
\hline
\end{tabular}

${ }^{a}$ Estimation terminated at iteration number 20 because maximum iterations have been reached

participant selected because of their economically disadvantaged families. This resulted majority of them were currently unable to create their own business. Therefore, stakeholders and development partners, i.e., government should facilitate financial support through a long-term loan payment from micro-finance institutions and lease machines.

Implication 4: redesigning the program will be required because providing training alone cannot bring livelihood changes as the finding of the study revealed. The beneficiaries of the program were selected from an economically poor family background. Therefore, the program should evaluate once again for financial and equipment support since the majority of the trainees were unemployed and seeking support from different development stakeholders in the three clusters.

\section{Abbreviations}

PRIME: Pastoralist Resilience Improvement through Market Expansion; ILO: International Labor Organization; TVET: Technical and Vocational Education and Training

\section{Acknowledgements}

The author would like to thank Haramaya University for supporting logistics and personal expenses during field survey data collection.

\section{Author's contributions}

The author administered all the processes starting from data collection, writing up the report, and policy implications. The author contributed to all investigation activities pertinent to the study, preparation of the report and corrections based on comments from the reviewers. The author read and approved the final manuscript.

\section{Author's information}

Robson Mekonnin Shiferaw is an assistant professor and researcher at Haramaya University, College of Business and Economics.

\section{Funding}

None

Availability of data and materials

The data cannot be shared because of some technical constraints.

\section{Competing interests}

The author declares no competing interests.

Received: 21 March 2019 Accepted: 28 July 2020

Published online: 09 September 2020

\section{References}

Ayalew, Mulu M., Zeleke, Amare Sh., (2018). Modelling the impact of entrepreneurial attitude on self-employment intention among engineering students in Ethiopia. J Innov Entrep, ISSN 2192-5372, Springer, Heidelberg, Vol. 7, Iss. 8, pp. 1-27, doi. https://doi.org/10.1186/s13731-018-0088-1

Braunerhjelm P., (2010). Entrepreneurship, Innovation and Economic Growth. Past experiences, current knowledge and policy implications. Working Paper Series from Swedish Entrepreneurship Forum.

CEIQA (2009). Charting the roadmap to private higher education in Ethiopia. Proceedings of the Seven National Conferences on Private Higher Education Institutions (PHEls), In Ethiopia. Organized \& Sponsored by St. Mary's University College

Cooney TH., (2012). Entrepreneurship skills for growth-orientated businesses. Report for the Workshop on 'Skills Development for SMEs and Entrepreneurship', Copenhagen, 28 November

Dando P., I and Lebmeier M., (2020). A novel valuation model for medical intervention development based on progressive dynamic changes that integrates Health Technology Assessment outcomes with early-stage innovation and indicationspecific clinical success rates. J Innov Entrep. doi.https://doi.org/10.1186/s13731-019-0111-1 Springer.

Dekker M., and Hollander S., (2017). Boosting youth employment in Africa: what works and why? Synthesis report for the INCLUDE/MFA conference 30 May The Hague, the Netherlands INCLUDE Secretariat. 
Essuman A., (2018). Entrepreneurship and job creation for sustainable development in Ghana: the role of government as an Arbiter in shaping the institutional environment.

Greenstone M., \& Looney A., (2011). Building America's job skills with effective workforce programs. A Training Strategy to Raise Wages and Increase Work Opportunities

ILO (2011). Tracer methodology to measure longer term impacts on children and families of interventions against child Labour

ILO, (2017). Promoting social entrepreneurship and social capital. A practice guide to supporting social entrepreneurship and inclusiveness in rural communities

Khan, R., Khan, F., \& Khan, M. (2011). Impact of training and development on organizational performance. Global J Manag Bus Res, 11(7).

Krishnan, P \&Shaorshadze, Sh., (2013). Technical and vocational education and training in Ethiopia. Paper for the International Growth Centre - Ethiopia Country Programme.

Kritikos A., (2014). Productive entrepreneurs can invigorate the economy by creating jobs and new technologies, and increasing productivity. DIW Berlin, University of Potsdam, and IZA, Germany

Lowrey, Y. (2011). Estimating entrepreneurial jobs. Business creation. American Economic Association Annual Meeting

Mason C., and Brown R., (2014). Entrepreneurial ecosystems and growth oriented entrepreneurship. Entrepreneurial ecosystems and growth oriented entrepreneurship. The Haque, Netherlands, 7th November.

Noor, K., \& Dola, K. (2011). Investigating training impact on farmers' perception and performance. Int J Humanit Soc Sci, 1, 6.

Ooi, Y., \& Ahmad, S. (2012). A Study among University Students in Business Start-Ups in Malaysia: motivations and obstacles to become entrepreneurs. Int J Bus Soc Sci, 3, 19.

Oxenham J., Diallo A., Katahoire A., Mwangi A., \& Sall O., 2002. Skills and literacy training for better livelihoods. Africa Region Human Development Working Paper Series

Samineni S., (2018). Social entrepreneurship as a tool for sustainable development of women in rural India leading to economic empowerment. IOSR Journal of Business and Management (IOSR-JBM) e-ISSN: 2278-487X, p-ISSN: 2319-7668. Volume 20, Issue 2.

UNECA, (2014). Youth and innovation in Africa: harnessing the possibilities of Africa's youth for the transformation of the continent. United Nations Economic Commission for Africa.

Yildirim N., Cakir O., \& Aşkun O., (2016). Ready to dare? A case study on the entrepreneurial intentions of business and engineering students in Turkey. Procedia - Social and Behavioral Sciences. Published by Elsevier Ltd.

\section{Publisher's Note}

Springer Nature remains neutral with regard to jurisdictional claims in published maps and institutional affiliations.

\section{Submit your manuscript to a SpringerOpen ${ }^{\circ}$ journal and benefit from:}

- Convenient online submission

- Rigorous peer review

- Open access: articles freely available online

High visibility within the field

- Retaining the copyright to your article

Submit your next manuscript at $\boldsymbol{s p r i n g e r o p e n . c o m ~}$ 